\title{
WHO STAYS, WHO WALKS, AND WHY IN HIGH-INTENSITY SERVICE CONTEXTS
}

Catherine Prentice, Swinburne University

February 2013

Send correspondence to Catherine Prentice, Faculty of Business \& Enterprise, Swinburne University, Australia (cathyjournalarticles@gmail.com). 


\title{
WHO STAYS, WHO WALKS, AND WHY IN HIGH-INTENSITY
}

\section{SERVICE CONTEXTS}

\begin{abstract}
The current investigation explores relationships among customer service-quality evaluations, propensity-to-switch, and player retention in a highly-intense service delivery environment (casinos). The study also examines the proposal that player loyalty intervenes between casino service-quality perceptions and player retention. Overall customer servicequality perception is operationalized as a multi-dimensional construct, consisting of service environment, empathy, reliability, assurance, responsiveness, game service, and food service. Path analyses show that casino service environment is the only factor that impacts player propensity-to-switch, whereas food service and empathy affect player retention. After separating the sample into three groups based on respondents' average betting, namely low-end, medium and high-end players, the influence of casino service factors on player propensity-to-switch and retention varies substantially among the groups. Results for testing the mediation model demonstrate that customer loyalty affects player retention and that casino service evaluations influence customer loyalty directly. A few measured factors such as age, education, occupation, and income influence player propensity-to-switch and retention. These findings have strategic implications for casino marketers.
\end{abstract}

Keywords: casino service quality; customer loyalty; player retention; player propensityto-switch 


\section{Introduction}

Macau is the top revenue market in the casino business globally. Competition in Macau is now intense among the various establishments: 39 casinos in a landmass of less than $30 \mathrm{~km}^{2}$ compete for the most lucrative players. The casino industry is transitioning from a traditional monopoly-style model into a more internationalized open market where competition is unpredictable and not necessarily confined to local jurisdiction. Thriving in this fast changing environment, casino marketers are learning that a necessary ingredient in competitive advantage recipes includes establishing and maintaining good relationships. Good customer relationships increase player retention rates and casino profitability (see Kale and Klugsberger, 2007; Watson and Kale, 2003). Beyond accepting this positive relationship in aggregate terms how to establish positive and sustainable customer relationships for casino practitioners remains an on-going challenge. The status quo of casinos in Macau appears to be that minor switching barriers exist between various establishments - players can and do switch and do so often. Hence, another challenge for casino marketers is how to retain players.

Service quality is an antecedent of customer loyalty and retention (Bell, Auh, and Smalley, 2005; Kheng, Mahamad and Ramayah, 2010; Ramzi and Mohamed, 2010; Zeithaml, Berry, and Parasuraman, 1996). However, very limited research is available that confirms this relationship in high-intensity contexts such as casinos. Whether or not marketers in casinos are fully aware of the factors in securing and quantifying player loyalty is doubtful (Lam, 2010). Assuming that players will return unconditionally is naïve based on the casino financial performance in the past few years.

Zeng, Prentice, and King (2012) detect a gamblers' adaptation effect in their comparison of visitor profiles between casino gamblers and non-gamblers. The effect indicates that gamblers who patronized casinos in Macau in the past few years are losing their novelty and spontaneity (see Zeng et al., 2012). Casino marketers' awareness of this effect may facilitate developing appropriate marketing strategies for achieving casino sustainability and competitive advantage. 
Following the foregoing discussion, the current study investigates the influence of casino service quality on player propensity-to-switch and retention. In her qualitative study, Prentice (2013) argues that service quality should be viewed as a multi-dimensional construct and reports that casino service quality dimensions have different effects in customer loyalty and retention, . Drawing on her study, this research employs a quantitative approach to examine what service causes customers to patronize the casino or to switch to competitors. Additionally, this study incorporates market segmentation based upon customers' betting volumes into analysis of the relationship between casino service and gambler loyalty. This research contributes to the literature by showing service quality to be a multidimensional construct and by incorporating market segmentation into customer loyalty research in the casino context. The findings of this study have strategic implications for casino practitioners and academics.

\section{Literature review}

\section{Casino service quality, player propensity-to-switch and retention}

Service quality involves customer perceptions of an entity's overall excellence or superiority (Parasuraman, Zeithaml, and Berry, 1988). Commonly acknowledged as an antecedent of customer satisfaction, service quality in turn drives customer loyalty and company profitability. Service quality impacts directly on customer behavioral intentions and that improved service quality enhances favorable intentions (Zeithaml, Berry, and Parasuraman, 1996).

Despite the extensive discussion within the relevant literature about service quality and its consequences, research on the relationship between service quality and customer retention within the casino context is scarce (see McCaina, Jang, and Hu, 2005). On the basis that customer preferences are key drivers of viability within the casino industry and that adopting a supply-led philosophy of "build it and they will come" is now an ineffective business model, gaming researchers, consultants and practitioners note the importance of service provision as a 
means of gaining competitive and sustainable advantage in the casino sector (Baird, 2002; Kale, 2006; Johnson, 2002; Stutz, 2008).

Thus, delivering quality service may be an effective relationship marketing tool for attracting patronage and maintaining customer loyalty in many retailing contexts. Customer evaluations of casino-service quality levels likely influence their loyalty so that high service quality is likely to reduce switching. Hence, the study proposes and tests the following hypothesis. H1a: Casino service-quality evaluations by customers associate negatively with their propensity-to-switch. H1b: Casino service quality associates positively with player retention.

\section{Service Quality Dimensionality}

Most research on service quality views the service quality construct as uni-dimensional or as a means of conveying the overall quality of a firm through delivering high quality services. Brady and Cronin (2001), Parasuraman, Zeithaml, and Berry (1985; 1988); and Ramzi and Mohamed (2010) assert that service quality is multi-dimensional and that attempting to use a uni-dimensional perspective is simplistic. For instance, Parasuraman et al. $(1985 ; 1988,1991)$ propose a service quality model, named SERVQUAL consisting of five dimensions: tangibles, reliability, responsiveness, assurance and empathy. Tangibles describe physical representations of the service and the appearance of the personnel. The other dimensions focus on the intangible aspects of the service and on the depiction of interpersonal interactions between customers and service representatives. Reliability refers to the accuracy that employees demonstrate in the performance of their duties - responsiveness to their promptness; assurance to trust and empathy to individual attention (Parasuraman et al., 1988).

Additional service quality models by Rust and Oliver (1994) and Brady and Cronin (2001) involve three components, namely service delivery, service environment and service product. The "Nordic Model" of service quality (i.e., Gronroos, 1984) consists of a functional 
component (the service delivery process) and a technical component (the outcomes). CASERV, a model by Wong and Fong (2011) to measure explicitly casino service, is a refinement of the model by Rust and Oliver (1994) and assesses four facets of casino service offerings: game service, service environment, food service, and service delivery. Game service represents the technical aspect of a service encounter, such as casino table games and slot machines. This technical aspect aligns with Gronroos' (1984) concept of technical quality and with Rust and Oliver's (1994) core or actual services. Service environment refers to the atmosphere and physical dimensions of the casino, consistent with the concept of "servicescape" (Bitner, 1992). Service delivery mainly depicts the service performance and behaviors of casino frontline employees and their interactions with customers. Food service plays a key role in the delivery of hospitality services (Ha and Jang, 2010 in Wong and Fong, 2011). These dimensions are classifiable as tangibles and intangibles.

Like many organisations offering service-oriented "products" casino services combine various dimensions involving the tangible and intangible. The tangible dimension includes physical facilities and gaming products such as games and slot machines, whereas the intangible refers largely to the services provided by frontline employees generally and by casino hosts in particular. Casinos typically offer a variety of tangible inducements to attract and retain players, particularly in the case of high rollers. Casino managers go to extreme lengths to accommodate the needs and wants of such players. Examples include distributing lavish gifts and redesigning hotel rooms to suit their preferences and idiosyncrasies (see Kale, 2005).

However, Prentice's (2013) qualitative study shows that such tangible offerings have minimal influence on their patronage to the casino; whereas a complimentary meal voucher or discounted hotel rates may suffice to prompt low-end players to return to the casino. The present paper extends Prentice's (2013) findings by adopting a quantitative stance to examine the relationships between the various dimensions of casino service quality and player loyalty with a focus on player propensity-to-switch to competitors and their actual patronage. The foregoing 
discussion informs the following hypothesis. H2a: Service quality dimensions have unique effects on player propensity-to-switch. H2b: service quality dimensions have unique effects on player retention. H2c: Such effects vary on different betting-volume players.

Customer loyalty and retention are distinctive constructs (Gerpott, Rams, and Schindler, 2001). Repetitive purchase (i.e., customer retention) is a direct outcome of customers with positive attitudes towards the service or brand - attitudinal loyalty (Bennett and Rundle-Thiele, 2002). Customer perceptions of the firm's service affect such attitudes (Prentice, 2013). Service quality perception, customers' attitude, and their subsequent purchasing behaviour likely function hierarchically. Prentice (2013) reports that gamblers' perceptions of casino services have impact on their loyalty which may influence their subsequent patronage. In other words, player loyalty may mediate the relationship between perception of casino service and player retention. H3: Player loyalty mediates the casino service quality and player retention relationship.

\section{Method}

\section{The study sample}

To test the hypotheses, a survey was designed and conducted at seven of the largest casino resorts in Macau. The sampling plan accommodated all relevant target audiences to achieve generalizability. The casinos agreeing to participate in the study designate various rooms within the gaming area to cater to different types of gamblers. Different gaming areas service tourists and regular low-end players, medium-volume players, and high rollers. The survey was undertaken at the non-gaming areas and questionnaires were administered randomly to all segments of players who were having breaks from playing.

\section{Measures}

This study opted for Parasuraman et al.'s SERVQUAL to measure casino service quality. Although various service quality measures exist in the relevant literature, SERVQUAL is the most widely 
used scale and is applicable across a broad spectrum of services, reported with good reliability and validity (Parasuraman et al., 1991). The original SERVQUAL measure involves 44 gap-based items including 22 items measuring customer perception of the firm's service performance and 22 items testing customer expectation.

Cronin and Taylor (1992) argue that the simple 22 performance items (customer perception of the firm's service performance) are adequate to define the service quality. This approach has been widely adopted in the literature and also in the casino context (e.g. Prentice et al., 2012; Prentice, 2013). The 22 performance-based items were adapted to test player perception of the casino service quality. Although the scale is valid across various services and industries, the scale developers (Parasuraman et al., 1991) suggest that supplementing SERVQUAL with a context-specific measures to fit in a specific study setting. Consistent with this suggestion, this study also used Wong and Fong's (2011)'s CASERV to measure casino service quality.

CASERV was developed by using a sample of casino players in Macau, and designed specifically to measure four dimensions of casino service quality, namely, service delivery, service environment, game service, and food service. However, items measuring the first two dimensions are similar to those in SERVQUAL. After deleting the repetitive items, 28 items were remained to measure 7 dimensions of casino service quality, namely, service environment, assurance, responsiveness, reliability, responsiveness, empathy, table service, and food service. The items are reworded to suit the study context. Additionally, this study used one item to measure player perception of casino's overall service quality.

Player propensity-to-switch (PPS) was measured by adapting the switch dimension of Zeithaml et al.'s (1996) "Behavioral-Intentions Battery” (BIB). The items were reworded to suit the study context after consulting with a number of senior casino marketing executives. Participants were asked to indicate their likelihood $(1=$ very unlikely; $7=$ very likely $)$ of switching to other casinos that offer better services and when they experience a service problem with the casino they used to patronise. The Cronbach's alpha coefficient for this adapted scale is .81 . 
Player loyalty (PL) was measured by items indicating their willingness to spread positive word-of-mouth, to recommend the casino to those who have not been there, and likeliness of considering the casino as their first choice. Player retention (PR) was assessed by respondents' actual annual visitation to the casino. Consistent with the criteria that these casinos used to categorise player visiting frequency, the researchers recorded these categories into a seven point Likert-type scale with 1 indicating least frequent, and 7 most frequent.

\section{Data collection}

The survey was undertaken outside the gaming area of the casinos. Prior to commencing the questionnaires, prospective participants were informed of the purpose of the investigation and assured of anonymity. A small gift was offered to participants as a means of encouragement to complete the survey. In total 411 completed and usable questionnaires were returned, amounting to $82.20 \%$ of the 500 surveys that were distributed. Of the total usable sample, 250 $(60.82 \%)$ were male, and $161(39.19 \%)$ were female. Most customers were over 25 years old, married and in full-time employment. A majority were either self-employed or held quite senior positions (e.g. management or supervisory). Almost 58 per cent of the respondents had a college education and over 55 per cent earned in excess of $\$ 50 \mathrm{k}$ per annum.

\section{Analysis and results}

\section{Factor analysis and validity testing}

The items that were used to measure casino service quality were factor analysed to confirm dimensionalities. A Pearson co-variance matrix and maximum likelihood estimation were used to determine the model fit (see Hu and Bentler, 1999). The results show that a sevenfactor model produced $\chi^{2}(130)=397.37, \mathrm{p}<.0005, \mathrm{SRMR}=.04$ and $\mathrm{RMSEA}=.05, \mathrm{CFI}=.98$ and TLI $=.97$, indicating a good model fit. The results of standardized residual co-variances and modification index values indicate no conspicuously significant changes to the model. The average variance extracted for each factor was over .50, indicative of adequate convergence 
(Fornell and Larcker, 1981). Furthermore, the composite reliability was acceptable for each of the factors. Factor loadings shown in Table 1 were positive and statistically significant. On this basis, the seven-factor model of casino service quality receives support.

\section{Table 1 here}

Additionally, two competing models were tested to analyze their factor structures, consistent with Wilkins, Merrilees and Herington's (2007) suggestion. The first model tested casino service quality as a first-order seven-factor model, and the second operationalized it as second-order construct, with the seven first-order factors being sub-dimensions. The results indicate that the first model is more desirable, as it produced better model fitting values (CFI = $\left..99, \mathrm{TLI}=.95, \mathrm{SRMR}=.04, \mathrm{RMSEA}=.05, \chi^{2}(209)=500.48, \mathrm{p}<.000\right)$. When the overall service quality ratings were regressed on the seven dimensions, the result shows a significant variance explained by these dimensions $\left(\mathrm{R}^{2}=.79, \mathrm{p}<.0005\right)$, indicating the scale validity. Hence, the first-order seven-factor casino service quality is used for subsequent analyses.

Table 2 shows that the seven factors correlate significantly $(\mathrm{p}<.01)$. The values range from .16 to .70 , indicating no redundancy or violation of multi-collinearity. Among the seven service quality factors, six are significantly related to the proposed criterion variables. The shared variances among these variables do not exceed 30 per cent, which suggests that they are empirically distinct constructs, and supports discriminant validity. The coefficients values indicate that all items have a significant loading on their corresponding constructs, demonstrating adequate convergent validity.

Insert Table 2 about here.

\section{Hypotheses testing}


For H1a, H1b, and H2a,b,c, the seven dimensions were used to assess the influence of casino service quality on the criterion variables. The results indicate that overall casino service quality explained 23 per cent variance in PPS $\left(\mathrm{R}^{2}=.23, \mathrm{p}<.0005\right)$, and 21 per cent in $\mathrm{PR}\left(\mathrm{R}^{2}=\right.$ $.21, \mathrm{p}<.0005)$. Among the seven factors, only service environment $(\beta=-.20, \mathrm{p}<.05)$ made substantial contribution to PPS; whereas PR is influenced by food service $(\beta=.22, \mathrm{p}<.05)$, empathy $(\beta=-.23, \mathrm{p}<.05)$. The findings confirm H1a, H1b, H2a and H2b. Namely, casino service quality associates significantly with PPS and PR, and various dimensions of casino service quality have different effects on the criterion variables.

To test $\mathrm{H} 2 \mathrm{c}$, the subjects are divided into three groups based on their average betting volumes: low-end players (LPs) with betting $\leq \$ 100$, medium volume players (MPs) with betting ranging from $\$ 100$ - 500 and high-end players (HPs) or high rollers with betting $\geq \$ 500$. This classification is consistent with that of the survey casinos. This division generated a sample size of 112 for LPs, 214 for MPs and 85 for HPs.

Results from multiple regression analyses indicate that the effects of service quality factors on the criterion variables (PPS and PR) vary across different groups. The results appear in Table 3a. H2c receives support. Specifically, responsiveness, assurance, empathy and reliability contribute to LPs' PPS, only empathy to MP's PPS, whereas service environment, assurance and reliability to HPs' PPS. The results from regressing PR against service quality factors show that responsiveness and assurance had significant influence on LPs' PR. Further analyses were undertaken to test the effects of casino service quality in PPS and PR by dropping the factors that were not significantly related to the criterion variables. The beta values for these variables appear in Table 3b. Interestingly, the results show that patronage declines as empathy increases for LP and MP segments. Figure 1 shows the effects. 
Structural equation modelling was conducted to test the mediation relationship (H3). The mediation relationship was tested by assessing two competing models, consistent with Singh, Goolsby, and Rhoads's (1994) approach. Following their method, direct effects between the casino service quality and player retention were estimated in the first model. The second model — the mediation model — involved estimating the effects of casino service quality on PL and PR, PL on PR. The mediation effect of PL is established in cases where the mediation model yields; (1) higher variances, (2) a significant relationship between casino service quality on PL, (3) substantially reduced or insignificant effects of casino service quality on PR, and (4) PL has a significant effect on PR.

The relationship between casino service quality and PR has been established in testing H1b. The mediation relationship (the second model) was assessed on the basis of standardized residual co-variances and modification index values. Drawing upon the model fit index values, the mediation model appears to fit the data reasonably well $\left(\chi^{2}(182)=861.69, \mathrm{p}<.0005, \mathrm{SRMR}\right.$ $=.05$ and $\mathrm{RMSEA}=.05, \mathrm{CFI}=.96$ and $\mathrm{TLI}=.96)$. Casino service quality explained 46 per cent in PL $(p<.0005)$, and PL explained 41 per cent in PR $(p<.0005)$. The mediation modelling testing shows that the relationship between casino service and PR is increased from 21 to 37 per cent by incorporating PL as a mediator. After PL was controlled, these effects between service quality factor and PR were reduced. The results in Table 4 support $\mathrm{H} 3$.

\section{Table 4 here}

Although overall casino service quality exerts significant influence on PPS and PR, results from beta coefficients show that only two out of the seven service quality dimensions had substantial effects in the criterion variables. In view of this, drawing on Zeng, Prentice, and King's (2012) study that demographic factors (namely, age, gender, education, income, employment status, and occupation) are related to gambling behaviors, further analyses were 
performed to examine the influence of player personal factors on PPS and PR. Logistic optimal scaling regression analyses were conducted to test these relationships. The results in Table 5 show that all factors except gender has significant influence on PPS and PR. One-way betweengroup analyses of variance (ANOVA) were undertaken to examine the mean difference of these factors across different groups. To assure adequate sample size and have a more accurate mean comparison, these variables except occupation are categorised into three groups after consulting with a senior casino marketing executive. The new categories have more practical implications for the practitioners.

The results indicate that, on the basis of Cohen's (1988) guidelines, statistically significant differences occur in PPS across groups of age and income at $p<.05$ level, but the differences in PR are significant across groups of age, education, occupation and income. Posthoc comparisons using Tukey's HSD test indicates that the mean scores for these demographic factors between the groups follow a steady increasing or decreasing trend for PPS as appearing in Tables 6. Specifically, the more senior (age) the players are, the higher income the players have, the less desirable occupation the players hold, and the less educated the players are, the less likely they would switch to competitors. For PR, the results indicate that the most frequently patronised players are business owner or high income earners, as well as the more senior group and the less educated.

Insert Table 5 and 6 about here

\section{Discussion and conclusions}

In addressing the claim that service quality is a key determinant of casino player loyalty, the present paper provides insights into the relationships among casino service quality, PPS (player propensity-to-switch) and PR (player retention). In particular, this study tested a mediation relationship between casino service quality, PL (player loyalty) and PR with PL as the 
proposed mediator. The survey was conducted with gaming-focused customers from a number of large casino resorts in Macau. Service quality was analyzed as a multidimensional construct and measured by a widely acknowledged measure (SERVQUAL) and a scale specifically designed for measuring casino service (CARSERV).

\section{Casino service and PPS}

The results show that the casino service environment impacts on player propensity-toswitch. Service environment that is measured in this study is concerned with the casino's physical facilities which include appearance of frontline employees, casino atmosphere, as well as the fellow customers in the casino premises. Casinos in Macau, though grand in general, have different physical appearance and architecture features. Players may have their individual preferences for certain settings and environment when selecting a casino to play.

Casinos do endeavour to cater for customers' preferences and idiosyncrasies as indicated by Kale (2005). However, it is unrealistic to satisfy customers in aggregate. Since personal factors from post hoc analyses demonstrate significant effect in PPS, casinos should look into these factors to segment customers. In alignment with organisational mission and marketing strategies, the casino should be designed to suit the target market. The finding that PPS is affected by fellow customers has implication for casino marketers. Fellow customers may be the best referrals. It is important to manage their word of mouth communication.

\section{Casino service and PR}

Among the seven factors of casino service quality, food service and employee empathy have significant effects in PR. Macau is famous for its delicacy. The finding indicates that gamblers would appreciate presence of such delicacy in the casino. Surprisingly, empathy has a negative effect on player patronage. Empathy is interpreted as the casino employees providing individualized attention to players and recognizing the regular customer. This negative influence indicates that customers do not wish to be identified, and perceive the attention from the casino to be unnecessary or unwelcome. This perspective may be attributed to sensitivity of gambling, 
particularly to those players from Mainland China where gambling is prohibited. Gambling is commonly understood to be the principal activity for visiting Macau. The visitors from the Mainland China would prefer not to be identified for social and political reasons. Therefore, the attention from the casino may increase their caution and awareness which discourage their further patronage.

\section{Casino service, PPS and PR among LPs, MPs and HPs}

When analysing the relationships among casino service quality, PPS and PR separately for customers with different betting volume, the results indicate empathy has unfavourable influence on keeping customers of the three segments (LPs, MPs and HPs) or attracting their patronage, particularly in the case of low- and medium-volume gamblers. This finding contrasts to that of Prentice (2013). In her study, empathy is a significant element achieving gambler loyalty, especially high rollers. However, the latter study was undertaken in a non-Macau context which may explain the discrepancy. The finding indicates that Chinese gamblers receive special attention from the casino unfavourably.

Results also show that LPs tend to switch to or patronage the casino that demonstrates responsiveness and assurance. Timely service (responsiveness) is important for these customers. The majority of them are tourist gamblers who often visit Macau in a group organised by travel agents. Casino visit is just part of the tour package, hence rather short. Assurance is measured with indicators like casino employees' knowledge and courtesy, and their trustworthiness. Its significant impact on LPs' casino visits indicates that customer value employees' information convening. Zeng et al.'s (2012) study shows that the majority of Macau visitors are first timers, particularly Chinese Mainlanders. These customers need to have a good understanding of the casino and its service provisions. Such information needs to be reliable to instil trust and confidence with customers.

Reliability demonstrates substantial effects in LPs' and HPs' intention to switch. Items that measure reliability include accuracy in billing and keeping records; and the service 
performed at the designated time. Most casinos, particularly those where the survey was undertaken, have loyalty or reward programs that are designed to attract customer loyalty and to track customer playing records which are used to reward customers according to specified criteria. Accuracy in billing and recording has direct impact on the rewards customers may be entitled. Casino service environment has a large effect in affecting HPs' intention to switch. In other words, these high rollers would patronize or switch to the casino that has a favorable atmosphere. Additionally, food service has a significant impact on keeping high rollers. Normally, these high rollers play in VIP gaming rooms in Macau casinos, and receive special service from the casino they stay and play. Casinos would do anything to cater to these customers (Kale, 2005). Food and beverage catering such as special delicacy and expensive French Champaign is one of such service that casinos use to attract their patronage.

\section{The mediation model}

Results from testing of structural equation modeling confirmed the mediation relationship between casino service quality, PL and PR. This finding indicates that customer/player attitude does play a role in determining their behavior (repetitive purchasing). From casino profitability perspective, the practitioners should look into the factors that affect player attitudes towards the casino. As the relevant literature suggests, customer attitudes are more reflective of their loyalty (AJzen, 1991; Phillip et al., 2004).

\section{Demographics and PPS and PR}

The results from analysing the relationship between personal factors and PPS and PR indicate that players' educational, financial and professional backgrounds have influence on their attitudes and behaviors. Through unrelated to the casino, such information can be used to facilitate marketing segmentation.

In summary, this study finds that customer intention (PL) intervenes between casino service quality and customer behavior (PR). Casino service environment, customers' 
educational, financial and professional backgrounds affect PPS. Whilst they prefer not to receive individual attention from the casino, players do value casino employees' knowledge, trustworthiness and reliability in their encounters with the casino. When analysing these relationships separately for different betting volume customers, it is found that low-end players' loyalty is attributed to a number of casino factors including reliability, assurance and responsiveness; food service impacts on higher-end gamblers. Individual attention paid by the casino may be misperceived by customers and frighten them away.

\section{Implications and suggestion for future research}

This study has theoretical and practical implications. The finding that casino service quality factors generate different effects on the criteria variables supports the perspective that service quality is viewable as a multi-dimensional construct. A single dimensional approach is insufficient for assessing service quality. Additionally, the analysis of service quality and its criterion variables should incorporate customer segmentation, as the current study shows that service quality exerts different effects in customer switching behaviors among different segments (LPs, MPs, and HPs in this study). To assure customers' loyalty and retention, casinos should look into service aspects that impact on specific segment's attitudes and behaviors.

In addition to studying casino factors, consider customers' personal information when analyzing their switching behaviors. Such information may assist casino marketers segmenting customers and developing appropriate marketing strategies. Although the study result indicates that only low-end players intend to switch, casinos should not trivialise this fact as these customers make steady contribution to casino revenues (Prentice, 2013).

Third, the significant mediation effect that player loyalty exerts indicates that customer attitudes relate to behavior. This relationship is consistent with the perspective of attitudinal and behavioral loyalty Dick and Basu (1994) propose. This conclusion has the practical implication that casino practitioners should not measure customer loyalty based on their actual visiting frequency. Customer attitudes play a significant role in their retention and repeat purchasing. 
Though a rigorous study, limitations arise from the investigation. Data for this study come from one location, Macau, though at various casinos. Future research should study these relationships by comparing casino players from different jurisdictions with a view to obtaining more generalizable findings. Future research should extend to casino frontline employees for they are likely to have unique and valuable information about customers' attitudes and intentional behaviors. 


\section{References}

Ajzen, I. (1991). “The theory of planned behavior." Organizational Behavior and Human Decision Processes. 50, 179-211

Bell, S.J., Auh, S. and Smalley, K. (2005). “Customer Relationship Dynamics: Service Quality and Customer Loyalty in the Context of Changing Customer Expertise and Switching Costs.” Journal of the Academy of Marketing Science. 33(2), 169-183

Bitner, M. J., and Hubbert, A. R. (1994). "Encounter satisfaction versus overall satisfaction versus quality.” In Rust, R.T. and Oliver, R.C. (eds) Service quality: New directions in theory and practice, pp 72-94 Sage, Thousand Oaks, California.

Brady, M.K, and Cronin, J.J. (2001). "Some new thoughts on conceptualising perceived service quality: a hierarchical approach.” Journal of Marketing. 65(3), 34-49

Chandon, J. L., Leo, P. Y., and Philippe, J. (1997). "Service encounter dimensions-a dyadic perspective: Measuring the dimensions of service encounters as perceived by customers and personnel.” International Journal of Service Industry Management, 8(1), 65-86.

Cronin, J. J., and Taylor, S. A. (1992). "Measuring service quality: a re-examination and extension.” Journal of Marketing, 56(3), 55-68.

Dick, A. and Basu, K., 1994. “Customer loyalty: towards an integrated framework.” Journal of the Academy of Marketing Science 22 (2), 99-113.

Ennew, C. T., and Binks, M. R. (1996). “The Impact of Service Quality and Service Characteristics on Customer Retention: Small Businesses and their Banks in the UK." British Journal of Management, 7(3), 219-230.

Gerpott, T.J., Rams, W. and Schindler, A. (2001). Customer retention, loyalty and satisfaction in the German mobile cellular telecommunications market. Telecommunications Policy, 25(4), 249-269

Gremler, D. D., and Gwinner, K. P. (2000). “Customer-employee rapport in service relationships.” Journal of Service Research, 3(1), 82-104. 
Gronroos, C. (1984). “A service quality model and its marketing implications.” European Journal of Marketing. 18(40), 36-44

Gu, Z., Siu, R.C.S. (2008). "Industry labour force quality: an investigation from the customer service perspective." UNLV Gaming Research and Review Journal. 12 (1/2), 1-13

Hallowell, R. (1996). “The relationships of customer satisfaction, customer loyalty, and profitability: an empirical study." International Journal of Service Industry Management, $7(4), 27-42$

Heskett, J. L., Jones, T. O., Loveman, G. W., Sasser, W., and Schlesinger, L. A. (2008). "Putting the service-product chain to work." Harvard Business Review, 72(2), 164-174. http://www.tandfonline.com/doi/abs/10.1080/15332969.2012.714700

Ingram, K.L., Cope, J.G., Harju, B.L. and Wuensch, K.L. (2000). “Applying to graduate school: A test of the theory of planned behavior." Journal of Social Behavior and Personality. $15(2), 215-226$.

Kale, S. H., and Klugsberger, P. (2007). "Reaping rewards" [Electronic Version]. Marketing Management, 16(4), 14-18.

Kale, S.H. (2005). “Optimally managing casino high-end market.” Bright Ideas, www.urbino.net

Kheng, L.L., Mahamad, O. and Ramayah, T. (2000). “The impact of service quality on customer loyalty: a study of banks in Penang, Malaysia.” International Journal of Marketing Studies. 2(2), 57-66

Klebanow, A.M. (2002). "Developing the casino marketing plan." UNLA Gaming Research and Review Journal. 6(2), 63-71.

Kumar,V. and Denish Shah (2004), "Building and Sustaining Profitable Customer Loyalty for the 21st Century," Journal of Retailing, 80 (4), 317-30.

Lam, D. (2010). No more "take it or leave it" service mentality in Macau. Macau Daily Times. 29 Sep, 2010. http://www.macaudailytimes.com.mo/opinion/17403-more-take-leaveservice-mentality-Macau.html 
Liljander, V., and Strandvik, T. (1995). “The nature of customer relationships in services.” Advances in services marketing and management, 4, 141-167.

Lucas, A.F. (2003). "The determinants and effects of slot servicescape satisfaction in a Las Vegas hotel casino." UNLV Gaming Research and Review Journal. 7(1), 1-19

MacDonald, A. (2002). "Dealing with high-rollers.” Urbino. Net/articles.

McCaina, S. L., Jang, S.C., and Hu, C. (2005). "Service quality gap analysis toward customer loyalty: practical guidelines for casino hotels.” Hospitality Management, 24, 465-472.

Oliver, R. L. (1993). “Cognitive, affective, and attribute bases of the satisfaction response.” The Journal of Consumer Research, 20(3), 418-430.

Parasuraman, A., Zeithaml, V. A., and Berry, L. L. (1988). “SERVQUAL: A Multiple-Item Scale for Measuring Consumer Perceptions of Service Quality.” Journal of Retailing 64(1), 12-40

Parasuraman, A., Zeithaml, V. A., and Berry, L. L. (1994). "Reassessment of expectations as a comparison standard in measuring service quality: Implications.” Journal of Marketing 58(1), 111-124 Rust,

Prentice, C (2013). "Service quality perceptions and customer loyalty in casinos." International Journal of Contemporary Hospitality Management. 25(3). 49-64

Prentice, C, King, B., \& Ohtsuka, K. (2012). “Service quality, tiered customer segments and casino player retention.” Services Marketing Quarterly. 33 (4), 277-291. DOI:

$10.1080 / 15332969.2012 .714700$

Ramzi, A.M. and Mohamed, B. (2010). “Customer loyalty and the impacts of service quality: the case of five star hotels in Jordan.” International Journal of Human and Social Science. $5(13), 886-892$

Rust, R. T., and Zaborik, A. J. (1993). “Customer Satisfaction, Customer Retention, and Market Share", Journal of Retailing 69(2), 193-215 
Storbacka, K., Strandvik, T., and Grönroos, C. (1994). "Managing customer relationships for profit: the dynamics of relationship quality." International Journal of Service Industry Management, 5(5), 21-38.

Strauss, A.L., and Corbin, J. (1990). Basics of qualitative research: grounded theory procedures and techniques. Sage, Newbury Park, California

Stutz, H. (2009). Serve customer, service yourself. 26(20). Las Vegas Business Press (10712186), p 14.

Suh, E., Erdem, M. (2009). "Gap analysis as a diagnostic tool for improving the slot gaming experience.” Journal of Hospitality Marketing and Management 18(4), 445-455

Tabachnick, B.G., \& Fidell, L.S. (2001). Using multivariate statistics (4 ${ }^{\text {th }}$ Edition). New York: HarperCollins

Watson, L., and Kale, S. H. (2003). "Know when to hold them: Applying the customer lifetime value concept to casino table gaming." International Gambling Studies, 3(1), 89-101.

Wong, I. A., and Fong, V. H. I. (2010). "Examining casino service quality in the Asian Las Vegas: An alternative Approach.” Journal of Hospitality Marketing and Management, 19(8), 842-865.

Woodside, A. G., Frey, L. L., and Daly, R. T. (1989). "Linking service quality, customer satisfaction, and behavioral intention.” Journal of Health Care Marketing, 9(4), 5

Zeithaml, V. A., Berry, L. L., and Parasuraman, A. (1996). “The behavioral consequences of service quality." Journal of Marketing, 60(2), 31-46

Zeithaml, V. A., Rust, R. T., and Lemon, K. N. (2001). "The customer pyramid: creating and serving profitable customers." California Management Review, 43(4), 118-142

Zeng Z.L., Prentice. C \& King., B (2012). To gamble or not? Perceptions of Macau among Mainland Chinese and Hong Kong visitors. International Journal of Tourism Research. http://onlinelibrary.wiley.com/doi/10.1002/itr.1902. 
Table 1

Confirmatory factor analyses results for casino service quality

\begin{tabular}{|c|c|c|c|c|c|}
\hline & Items & FL & $\alpha$ & CR & AVE \\
\hline \multirow{4}{*}{ SE } & The casino's ambience is comfortable & .94 & .87 & .87 & .70 \\
\hline & $\begin{array}{l}\text { The casino's physical facilities and appearance of personnel are } \\
\text { visually appealing }\end{array}$ & .97 & & & \\
\hline & Other customers in the casino are usually polite and behaving & .70 & & & \\
\hline & $\begin{array}{l}\text { Materials associated with the service such as décor and layout are } \\
\text { visually appealing and stylish }\end{array}$ & .91 & & & \\
\hline \multirow{5}{*}{ Rel } & $\begin{array}{l}\text { When the casino promises to do something by a certain time, it } \\
\text { does so }\end{array}$ & .85 & .91 & .92 & .77 \\
\hline & $\begin{array}{l}\text { When I have a problem, the casino shows a sincere interest in } \\
\text { solving it }\end{array}$ & .74 & & & \\
\hline & The casino performs the service right the first time & .79 & & & \\
\hline & The casino provides its services at the time it promises to do so & .95 & & & \\
\hline & The casino insists on error-free records & .93 & & & \\
\hline \multirow{4}{*}{ Res } & $\begin{array}{l}\text { Employees of the casino tell you exactly when the services will } \\
\text { be performed }\end{array}$ & .79 & .86 & .87 & .68 \\
\hline & Employees of the casino give you prompt service & .84 & & & \\
\hline & Employees of the casino are always willing to help you & .71 & & & \\
\hline & $\begin{array}{l}\text { Employees of the casino are never too busy to respond to your } \\
\text { requests }\end{array}$ & .89 & & & \\
\hline \multirow{4}{*}{ A } & The behavior of employees instils confidence in customers & .74 & .72 & .74 & .59 \\
\hline & You feel safe in your transactions with the casino & .79 & & & \\
\hline & Employees of the casino are consistently courteous with you & .83 & & & \\
\hline & $\begin{array}{l}\text { Employees of the casino have the knowledge to answer your } \\
\text { questions }\end{array}$ & .76 & & & \\
\hline \multirow{5}{*}{$\mathbf{E}$} & The casino gives you individual attention & .89 & .84 & .84 & .65 \\
\hline & The casino has operating hours convenient to all its customers & .91 & & & \\
\hline & The casino has employees who give you personal attention & .85 & & & \\
\hline & The casino has your best interests at heart & .87 & & & \\
\hline & Employees of the casino understand your specific needs & .82 & & & \\
\hline \multirow{3}{*}{ FS } & The casino offers a variety of food and beverage & .79 & .83 & .83 & .62 \\
\hline & The price of food and beverage is reasonable & .79 & & & \\
\hline & The quality of food and beverage is excellent & .77 & & & \\
\hline \multirow{2}{*}{ GS } & The casino has sufficient number of table games available & .85 & .89 & .90 & .74 \\
\hline & The casino has sufficient number of slot machines available & .92 & & & \\
\hline
\end{tabular}


Note: Fit indices: $\chi^{2}(130)=397.37, \mathrm{p}<.000, \mathrm{SRMR}=.04, \mathrm{RMSEA}=.05, \mathrm{CFI}=.98, \mathrm{TLI}=.97$, $\mathrm{SE}=$ service environment, Rel. $=$ reliability, $\mathrm{Res}=$ responsiveness, $\mathrm{A}=$ assurance, $\mathrm{E}=$ empathy, $\mathrm{FS}=$ food service, $\mathrm{GS}=$ game service, $\mathrm{FL}=$ factor loadings, $\alpha=$ Cronbach's alpha for this study, $\mathrm{CR}=$ composite reliability, Ave $=$ average variance extracted. 
Table 2

Correlations among the study variables

\begin{tabular}{lllllllll}
\hline & PR & PPS & PL & A & E & Res & Rel. SE GS FS \\
\hline PR & -- & & & & & \\
PPS & $-.14^{* *}$ & & & & & \\
PL & $.31^{* *}$ & $-.14^{* *}$ & & & & & & \\
A & $.55^{* *}$ & -.08 & $.55^{* *}$ & & & & \\
E & $.63^{* *}$ & $.14^{* *}$ & $.43^{* *} .69^{* *}$ & & & & \\
Res & $.46^{* *}$ & $-.19^{* *}$ & $.46^{* *} .70^{* *}$ & $.59^{* *}$ & & & \\
Rel. & $.63^{* *}$ & -.06 & $.43^{* *} .63^{* *}$ & $.61^{* *}$ & $.57^{* *}$ & & \\
SE & $.20^{* *}$ & $-.31^{* *}$ & $.31^{* *} .38^{* *}$ & $.29^{* *}$ & $.53^{* *}$ & $.24^{* *}$ & \\
GS & .06 & $-.31^{* *}$ & $.31^{* *} .24^{* *}$ & $.24^{* *}$ & $.38^{* *}$ & $.16^{* *} .68^{* *}$ & \\
FS & $.47^{* *}$ & $-.20^{* *}$ & $.46^{* *} .63^{* *}$ & $.65^{* *}$ & $.58^{* *}$ & $.62^{* *} .51^{* *} .39^{* *}--$ \\
\hline
\end{tabular}

** Correlation is significant at the .01 level (2-tailed)

*. Correlation is significant at the .05 level (2-tailed)

Key. $\mathrm{PR}=$ Player retention, $\mathrm{PPS}=$ player propensity-to-switch, $\mathrm{PL}=$ player loyalty, $\mathrm{A}=$ Assurance, $\mathrm{E}=$ Empathy, Res = Responsiveness, Rel. = Reliability, SE = Service environment, $\mathrm{SD}=$ Service delivery, $\mathrm{GS}=$ Game service, $\mathrm{FS}=$ Food service 
Table 3a

Results for the relationships between casino service quality, PPS and PR for all participants as well as for LPs, MPs and HPs, beta coefficients

\begin{tabular}{|c|c|c|c|c|c|c|c|c|}
\hline & \multicolumn{4}{|c|}{ Player propensity-to-switch } & \multicolumn{4}{|c|}{ Player retention } \\
\hline & Total & LPs & MPs & HPs & Total & LPs & MPs & HPs \\
\hline SE & $-.20 * *$ & -.16 & -.13 & $-.29 * *$ & .11 & .01 & .04 & .11 \\
\hline Res. & -.03 & $-.26^{*}$ & -.08 & -.09 & .06 & $.36^{* *}$ & .05 & .06 \\
\hline A & -.09 & $-.35^{* *}$ & -.01 & $-.18 *$ & .05 & $.42 * *$ & .13 & .05 \\
\hline GS & -.13 & -.06 & -.12 & -.04 & .09 & .02 & .15 & .09 \\
\hline FS & -.07 & -.15 & -.01 & -.05 & $.22 * *$ & .06 & .06 & $.23 *$ \\
\hline $\mathrm{E}$ & .15 & $.32 * *$ & $.20^{*}$ & -.03 & $-.23 * *$ & $-.35 * *$ & $-.42 * * *$ & -.13 \\
\hline Rel. & -.15 & $-.32 * *$ & -.14 & $-.18 *$ & .09 & .14 & .06 & .08 \\
\hline \multicolumn{5}{|c|}{ Model summaries for PPS } & \multicolumn{4}{|c|}{ Model summaries for PR } \\
\hline \multicolumn{5}{|c|}{$\mathrm{R}^{2}($ total $)=.23, \mathrm{~F}(7,403)=28.62 * * *$} & \multicolumn{4}{|c|}{$\mathrm{R}^{2}($ total $)=.21, \mathrm{~F}(7,403)=21.06^{* * *}$} \\
\hline \multicolumn{5}{|c|}{$\mathrm{R}^{2}(\mathrm{LPs})=.16, \mathrm{~F}(7,104)=12.72 * * *$} & \multicolumn{4}{|c|}{$\mathrm{R}^{2}(\mathrm{LPs})=.22, \mathrm{~F}(7,104)=17.31 * * *$} \\
\hline \multicolumn{5}{|c|}{$\mathrm{R}^{2}(\mathrm{MPs})=.20, \mathrm{~F}(7,206)=19.34 * * *$} & \multicolumn{4}{|c|}{$\mathrm{R}^{2}(\mathrm{MPs})=.15, \mathrm{~F}(7,206)=15.14 * * *$} \\
\hline \multicolumn{5}{|c|}{$\mathrm{R}^{2}(\mathrm{HPs})=.26, \mathrm{~F}(7,77)=17.80 * * *$} & \multicolumn{4}{|c|}{$\mathrm{R}^{2}(\mathrm{HPs})=.17, \mathrm{~F}(7,77)=15.48^{* * *}$} \\
\hline
\end{tabular}

$$
* \mathrm{p}<.05, * * \mathrm{p}<.01, * * * \mathrm{p}<.0005
$$

Note: Total $=$ coefficient values for all participants, $\mathrm{A}=$ Assurance; $\mathrm{SE}=$ Service environment; $\mathrm{E}=$ Empathy; Res = Responsiveness; Rel. = Reliability; GS = game service, $\mathrm{FS}=$ Food service, LPs $=$ Low-end players, MPs $=$ Medium players, HPs $=$ High-end players, $\mathrm{PPS}=$ player propensity-to-switch, $\mathrm{PR}=$ Player retention 
Table 3b

Parsimonious models, Beta Coefficients

Player propensity-to-switch

Player retention

\begin{tabular}{|c|c|c|c|c|c|c|c|c|}
\hline & Total & LPs & MPs & HPs & Total & LPs & MPs & HPs \\
\hline SE & $-.20 * *$ & & & $-.24 * *$ & & & & \\
\hline Res. & & $-.38 * *$ & & & & $.35 * *$ & & \\
\hline A & & $-.27 * *$ & & -.12 & & $.44 * *$ & & \\
\hline \multicolumn{9}{|l|}{ GS } \\
\hline FS & & & & & $.15 * *$ & & & $.23^{*}$ \\
\hline $\mathrm{E}$ & & $.35^{* *}$ & $-.28 * *$ & & $-.24 * *$ & $-.45 * *$ & $-.34 * *$ & -.14 \\
\hline Rel. & & $-.34 * *$ & & $-.21 *$ & & & & \\
\hline \multicolumn{5}{|c|}{ Model summaries for PPS } & \multicolumn{4}{|c|}{ Model summaries for PR } \\
\hline \multicolumn{5}{|c|}{$\mathrm{R}^{2}($ total $)=.12, \mathrm{~F}(1,408)=18.07 * * *$} & \multicolumn{4}{|c|}{$\mathrm{R}^{2}($ total $)=.09, \mathrm{~F}(1,409)=10.27 * *$} \\
\hline \multicolumn{5}{|c|}{$\mathrm{R}^{2}(\mathrm{LPs})=.10, \mathrm{~F}(4,107)=9.01 * * *$} & \multicolumn{4}{|c|}{$\mathrm{R}^{2}(\mathrm{LPs})=.21, \mathrm{~F}(3,108)=9.64 * * *$} \\
\hline \multicolumn{5}{|c|}{$\mathrm{R}^{2}(\mathrm{MPs})=.09, \mathrm{~F}(2,211)=10.15^{* * *}$} & \multicolumn{4}{|c|}{$\mathrm{R}^{2}(\mathrm{MPs})=.12, \mathrm{~F}(1,212)=17.95 * * *$} \\
\hline \multicolumn{5}{|c|}{$\mathrm{R}^{2}(\mathrm{HPs})=.27, \mathrm{~F}(3,80)=9.98 * * *$} & \multicolumn{4}{|c|}{$\mathrm{R}^{2}(\mathrm{HPs})=.11, \mathrm{~F}(2,56)=6.21 * * *$} \\
\hline
\end{tabular}

$$
{ }^{*} \mathrm{p}<.05, * * \mathrm{p}<.01, * * * \mathrm{p}<.0005
$$

Note. Total $=$ coefficient values for all participants, $A=$ Assurance; $S E=$ Service environment; $\mathrm{E}=$ Empathy; Res = Responsiveness; Rel. = Reliability; GS = game service, $\mathrm{FS}=$ Food service, LPs $=$ Low-end players, MPs $=$ Medium players, HPs $=$ High-end players, $\mathrm{PPS}=$ player propensity-to-switch, $\mathrm{PR}=$ Player retention 


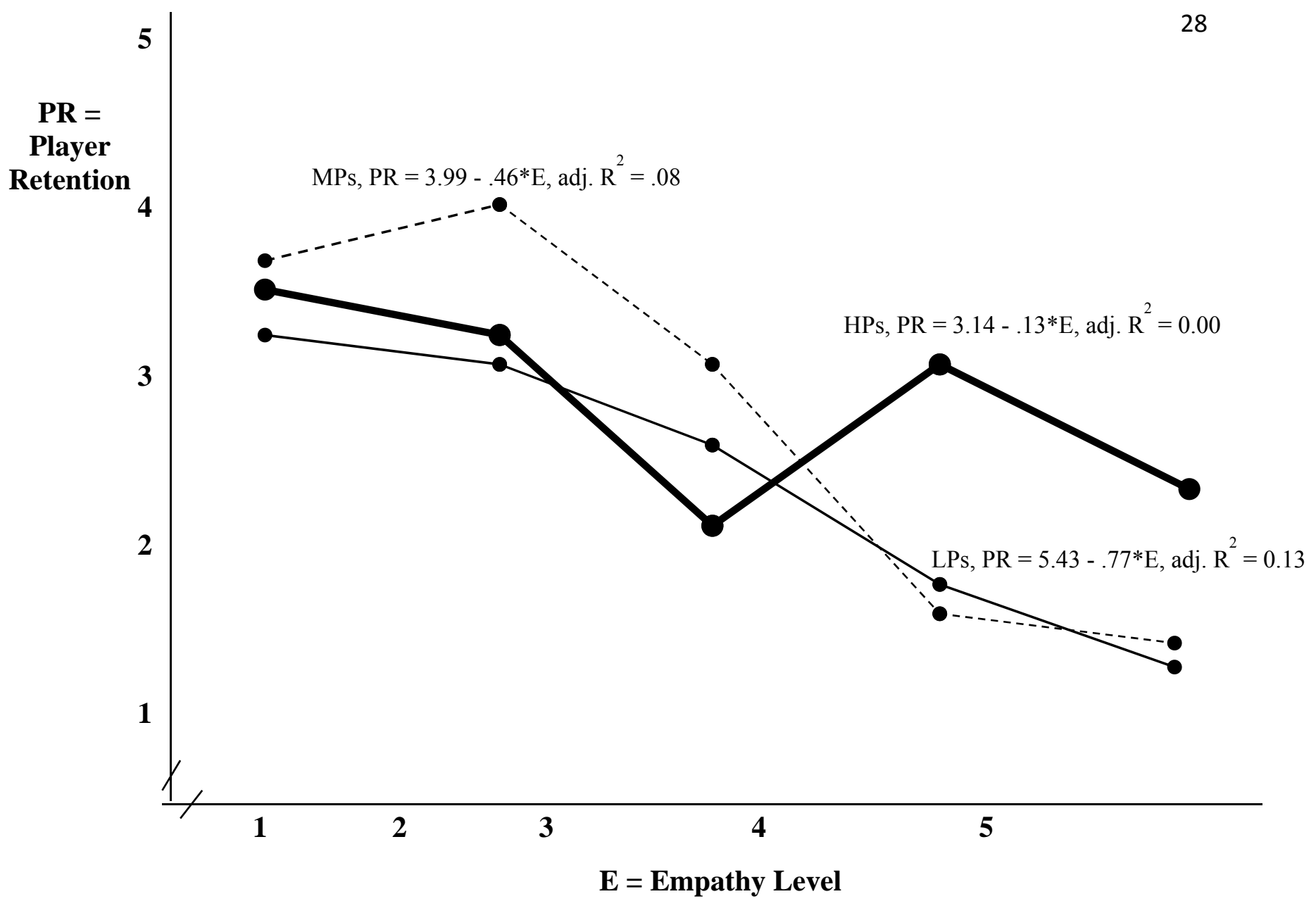

Figure 1

The Relationship between Empathy Perceived by Guests and Player Retention among Low (LPs), Medium (MPs), and High Volume (HPs) Players 
Table 4

Results of mediation model testing: PL as a mediator between casino service quality and PR

\begin{tabular}{|c|c|c|}
\hline Parameter & $\begin{array}{l}\text { direct effects } \\
\text { model }\end{array}$ & mediation model \\
\hline Structural path & $\begin{array}{l}\text { standardised } \\
\text { coefficients }\end{array}$ & $\begin{array}{l}\text { standardised } \\
\text { coefficients }\end{array}$ \\
\hline $\mathrm{A} \rightarrow \mathrm{PL}$ & & .07 \\
\hline $\mathrm{SE} \rightarrow \mathrm{PL}$ & & .06 \\
\hline $\mathrm{E} \rightarrow \mathrm{PL}$ & & $.32 * * *$ \\
\hline Res. $\rightarrow$ PL & & .08 \\
\hline Rel. $\rightarrow$ PL & & $.25 * * *$ \\
\hline $\mathrm{GS} \rightarrow \mathrm{PL}$ & & $.16^{* *}$ \\
\hline $\mathrm{FS} \rightarrow \mathrm{PL}$ & & .04 \\
\hline \multicolumn{3}{|c|}{$\mathrm{R}^{2}=.46$ for casino service quality in $\mathrm{PL}$} \\
\hline $\begin{array}{l}\mathrm{PL} \rightarrow \mathrm{PR} \\
\mathrm{R}^{2}=.31 * * * \text { for }\end{array}$ & n PR & $.51 * * *$ \\
\hline $\mathrm{A} \rightarrow \mathrm{PR}$ & .05 & .03 \\
\hline $\mathrm{SE} \rightarrow \mathrm{PR}$ & .11 & .07 \\
\hline $\mathrm{E} \rightarrow \mathrm{PR}$ & $-.23 * *$ & -.13 \\
\hline Res. $\rightarrow$ PR & .06 & .01 \\
\hline Rel. $\rightarrow$ PR & .09 & .06 \\
\hline $\mathrm{GS} \rightarrow \mathrm{PR}$ & .09 & .06 \\
\hline $\mathrm{FS} \rightarrow \mathrm{PR}$ & $.22 * *$ & .05 \\
\hline$R^{2}$ & $.21 * * *$ & $.37 * * *$ \\
\hline \multicolumn{3}{|l|}{$\begin{array}{l}\text { Goodness of } \\
\text { Fit Statistics }\end{array}$} \\
\hline$\chi^{2}$ & & 861.69 \\
\hline df & & 182 \\
\hline RMSEA & & .05 \\
\hline NNFI & & .96 \\
\hline CFI & & .96 \\
\hline
\end{tabular}

$* \mathrm{p}<.05 ; * * \mathrm{p}<.01 ; * * * \mathrm{p}<.0005$.

Note. The direct effects and the mediation models include the direct effects between seven dimensions of service quality and PR. RMSEA = root mean square error of approximation; NNFI - non-normed fit index; CFI - comparative fit index; $\mathrm{A}=$ Assurance; $\mathrm{SE}=$ Service environment; $\mathrm{E}=$ Empathy; Res = Responsiveness; Rel. = Reliability; GS = game service, $\mathrm{FS}=$ Food service, $\mathrm{PL}=$ player propensity to return, $\mathrm{PR}=$ Player Retention. 
Table 5

Optimal Scaling Regression Analyses Findings for Personal factors predicting player Propensity-to-Switch and Player Retention

\begin{tabular}{lllll}
\hline & beta1 & beta 2 & $\mathrm{R}^{2}(\mathrm{~F} 1)$ & $\mathrm{R} 2{ }^{2}(\mathrm{~F} 2)$ \\
\hline Sex & -.05 & .05 & $.00(3.80)$ & $.00(1.61)$ \\
Age & $-.16^{*}$ & $.17^{*}$ & $.03(5.47)$ & $.03(6.01)$ \\
Education & $-.18^{*}$ & $.16^{*}$ & $.03(6.13)$ & $.03(6.10)$ \\
Employment Status & $-.13^{*}$ & $.18^{*}$ & $.02(8.80)$ & $.03(7.02)$ \\
Occupation & $-.17^{*}$ & $.13^{*}$ & $.03(5.80)$ & $.02(5.03)$ \\
Monthly Income & $-.15^{*}$ & $.12^{*}$ & $.02(4.74)$ & $.01(4.04)$ \\
\hline
\end{tabular}

Note: Beta 1, R12 and F1 values for player propensity-to-switch PPS, beta $2, \mathrm{R} 2^{2}$ and F2 values for player retention 
Table 6

ANOVA results for the relationships between demographics with PPS and PR

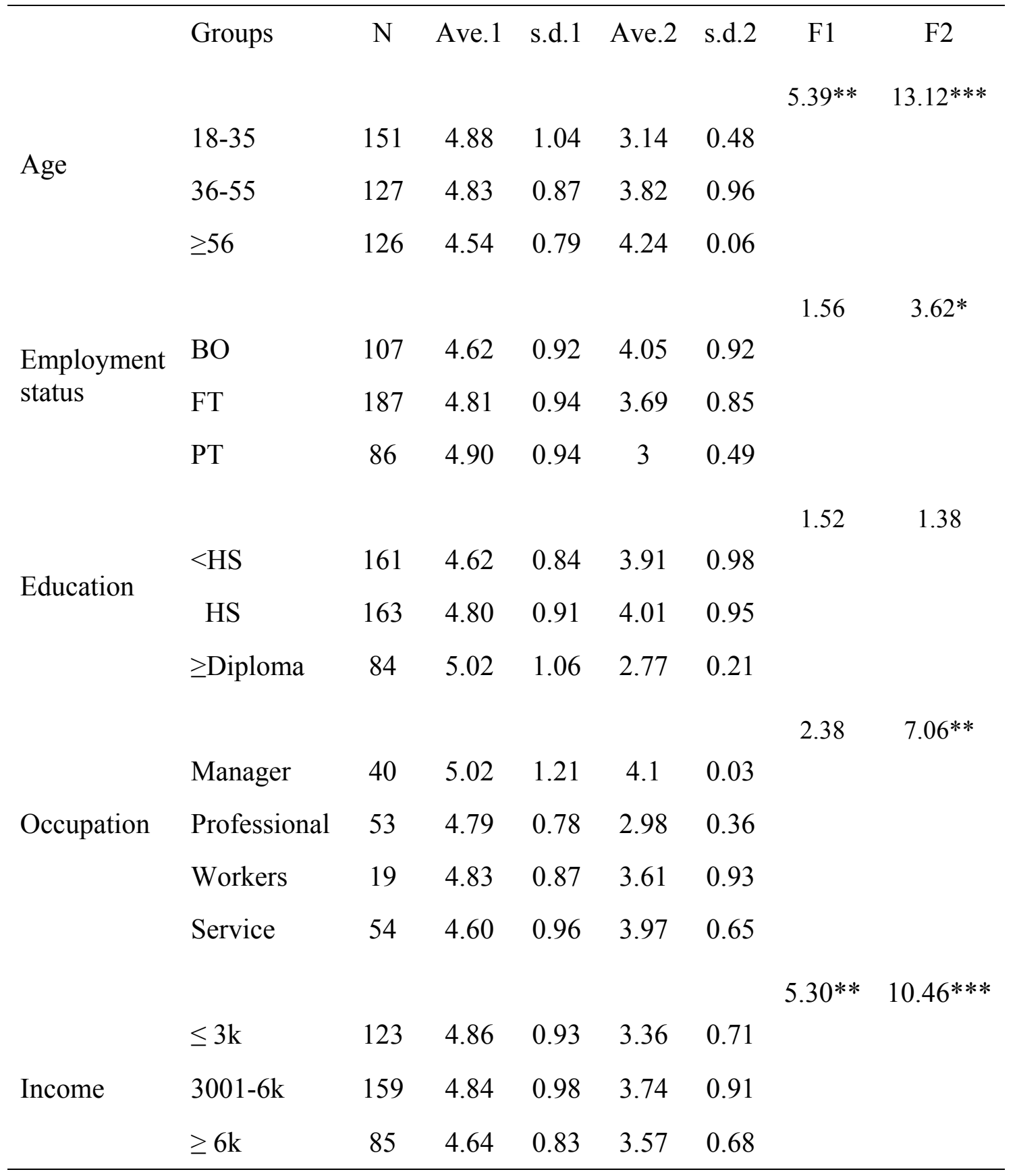

Note: ${ }^{*} \mathrm{p}<.05 * * \mathrm{p}<.01 * * * \mathrm{p}<.0005$.

Note. $\mathrm{HS}=$ high school. $\mathrm{BO}=$ business owner, $\mathrm{FT}=$ full timers, $\mathrm{PT}=$ Part timers, Ave.1, s.d.1 and F1 values for player propensity to switch, Ave.2, s.d.2 and F2 for player retention; Ave. = average; s.d. $=$ standard deviation. 